\title{
Література:
}

1. Кассен Б. Більше однієї мови / Пер. 3 фр. С. Желдак. Київ : ДУХ І ЛІТЕРА, 2016. $64 \mathrm{c}$.

2. Ключ до України : міста і люди : підручник з української мови як іноземної (Рівні В2-С1) / [Ключковська І., Горда О., Трумко О., Мартинишин Н., Темник Г., Руснак О.] - Ч. 2. - Львів : Колір ПРО, 2020. 296 с.

3. Назаревич Л. Т., Гавдида Н. І. Українська мова для іноземців. Практикум (Рівні В1-В2). Тернопіль : ФОП Паляниця В. А., 2017. 212 с.

4. Назаревич Л., Денисюк Н. Пісенна творчість - компонент методики навчання української мови як іноземної // Актуальні проблеми лінгводидактики в сучасному освітньому середовищі : матеріали Всеукраїнської науково-практичної інтернет-конференції (з міжнародною участю) / за заг. ред. Г. Дідук-Ступ’як, Т. Миколенко, М. Пігур. 2-ге вид., перероб. і доп. Тернопіль : Вектор, 2020. 258 с.

5. Швець Г. Теорія і практика навчання української мови іноземних студентів гуманітарних спеціальностей : монографія. Київ : Фенікс, 2019. $529 \mathrm{c}$.

DOI https://doi.org/10.30525/978-9934-26-039-1-88

\section{VOCATIVES IN ENGLISH AND UKRAINIAN}

\section{Sokolets I. I.}

Candidate of Pedagogical Sciences, Associate Professor, Associate Professor at the Department of Germanic and Finno-Ugric Philology named after Professor G. G. Pocheptsov

Kyiv National Linguistic University

Kyiv, Ukraine

\section{Khanykina N. V.}

Candidate of Philological Sciences,

Senior Researcher at the Scientific Research Laboratory of Education Borys Grinchenko Kyiv University

Kyiv, Ukraine

Vocatives are an important component of communication. These words and expressions are widely used in almost all languages to call «the attention of an addressee, in order to establish or maintain a relationship between this addressee and some proposition» [3, p. 267]. 
Since distribution of bare vocatives and vocatives with determiners is cross-linguistic and language-specific, it is interesting to analyze the peculiarities of their use in different languages. We will consider common and distinctive features of their functioning in English and Ukrainian.

Vocative expressions may perform different functions: a conative, phatic, referential, emotive and even poetic; depending on the context, they may perform several functions at the same time. In our research we will consider vocatives in a narrow sense: as nouns or noun phrases that identify or describe the addressee.

So, vocative is a word or phrase used to address a person directly, usually in the form of a personal name, title or term of endearment [4].

Vocative or address is one of the most common means of both positive and negative politeness in both languages, English and Ukrainian, since it expresses the speaker's attitude toward the interlocutor. It acts in the language as stable etiquette codes that allow to identify the addressee, making a primary verbal contact with the interlocutor and identifying the position of the communicants in the system of social hierarchy, so the formulas are socially marked. Therefore, the main factors which influence the choice of the addressing formula are the social status of communicants and the communicative situation.

Both in English and in Ukrainian, address may be expressed by:

- personal names;

- respectful and formal terms or honorifics such as «Mr.», «Mrs.», «Sir», «Madaте», «Пане (i)», «Шановний $(a) »$;

- titles such as «Doctor», «Professor», «Mајог», «Лікарю», «Вчителю»;

- kinship terms which can be used literally and metaphorically;

- terms of endearment in addressing children or close and intimate people such as «honey», «sweetie», «buddy» «kitty», «любий(a)», «милий (a)»;

- colloquial or slang addresses, such as «dude», «bro», «братан», «бро»;

- nicknames derived from proper names or personal characteristics of the addressee, such as «Mr. Know-all», «Mrs. Perfection», «Tiny kitty».

Many forms of address are model units, which are produced by structural schemes, for instance: Товариш (громадянин) + surnaтe; Товариш + the name of the profession/position/occupation; name (including diminutive names); Mr./Mrs. + name/surname; name and patronymic, etc.

The addressing etiquette system in the Ukrainian language has undergone in its historical development great changes related to the social organization of the society. Earlier such addressing formulas as «Товаришу», «Добродію», «Громадянине» were popular. Formulas «Громадянко» and «Громадяни» are limited to legal, juridical sphere. The formula «Громадянко» helps 
emphasize the equality of all members of the society to the law as people enjoying civil rights and having certain responsibilities.

The address «Tоваришу» appeared in the Ukrainian language at the end of the XIX and the beginning of the XX centuries. It was used in the intellectual environment and meant «a person connected with anyone by friendship» or «a man, ideologically connected with others». In Soviet times, the word replaced all other addresses and functioned for naming party colleagues.

"Добродію» («Добродійко», «Добродіï») is the ancient honorific form of address to people who do good deeds. It was widespread mostly in Eastern Ukraine and used in combination with etiquette attributes «Вельмишановний» and «Вельмиповажний».

The address «Товариство!» is more frequently used, especially, to a group of people that are associated with some communion (interests, position in society, etc.) .

The English use «Dear sirs», "Dear colleagues» and "Dear friends». «Your Majesty!», «Father Jack!» or «Colonel Johnson!» as a form of address to a large audience, an indication of a person's position in a society. In some cases address is used just in order to show appreciation. There are special forms of address for the expression of respect to people of a certain social class, for example: "Ladies and Gentlemen», "Your Excellency», "Your Highness», «Mr. President» and «Prime Minister».

The choice of the address formula largely depends on the style of communication. In official communication «Пані» and "Панове» are used [1, c. 78]. «Пан» is used addressing a man; «Пані» is used addressing a woman. In official communication these addressing formulae are combined with the surname of the person. In this way the strategy of negative politeness is realized, since it is typical of negative politeness to emphasize the importance of the addressee. There is one more formula of formal address in Ukrainian: Шановний/Вельмишановний + naте and patronymic.

At the same time, in English there is a similar rule: the strategy of negative politeness is realized with the help of Sir/Madam/Mr/Mrs + surname. In communication between friends, names are usually used, but in conversation with less close people they use "Miss», «Mrs», «Mr» and the last name. «Miss» is used, referring to a girl or an unmarried woman; «Mrs» is used, addressing a married woman; «Mr» is used when addressing a man [1, c. 230].

In modern English addressing by name is acceptable in such relationships: children - adults (if they are relatives); subordinates and their chiefs, students - teachers, indicating the equality of communicants, regardless of their age and status. Such addressing formulas demonstrate friendly relationship between 
people and friendly attitude to each other. In this way the positive politeness strategy is implemented.

Another means of demonstrating intergroup affiliation in English communication is diminutive names, that is, abbreviated forms of complete names, for example, Robert - Rob, David - Dave, and names with diminutive suffixes such as Tommy, Eddie. It is believed that using diminutives when referring to other people is a way to get closer to them.

In the Ukrainian culture, addressing by name to a senior person or a person higher in rank is impolite. It is considered familiar and not allowed by the rules of speech etiquette. Diminutive names are often used in the Ukrainian language too but their use demonstrates close relationships between people.

To show respectful attitude in the Ukrainian language, the name and patronymic and the pronoun $\langle B u »$ are used. However, it is appropriate to address by name a subordinate or a younger person. In modern English such an opposition does not exist, because the pronoun «thou» which used to be a second person singular pronoun in English, was replaced by «you» in New English Period [2, c. 83]. In the live communication the respectful plural form of the pronoun you «Bu» may be used, addressing a single interlocutor, if he/she is unfamiliar, older or higher in rank. This emphasizes respect to the interlocutor. " $B u$ » expresses close relationship between people. It conveys respect, which is based on friendship, sociability or love. Friends, colleagues, employees, siblings, spouses use «mu», communicating with each other.

Taking into account the lexical-semantic characteristics of address, it is worth noting that in the Ukrainian language «дiдy», «бабо», «дядьку», «тітко» can be used addressing both relatives and people who are not related by kinship. In English the formulas "grandmother (grandma)», "grandfather (grandpa)», «uncle», «aunt» are used only in relation to relatives [1, c. 345].

Both in Ukrainian and in English some names of professions are used as addressing formulae [1, c. 425] For example, «Teacher» is not used as a form of address, but «Doctor» and «Nurse» are used.

An important characteristic of address is that it can give an evaluative characteristic, have an expressive coloring and show the attitude of the speaker to the interlocutor. In both languages, diminutive and caressing words are used as an address to relatives and close friends. The English most often call their relatives «sweetheart», «sweetie» and «darling».

Ukrainian people use such caressing words and terms of endearment as «Любий», «Милий», "Серденько» and "Дорогий». But there is a difference between the English «Dear» and the Ukrainian «Дорогий», which is used by friends, relatives and familiar people, combined with $m u$-forms of communication. 
Phraseological units, such as: angel of light, and broth of a boy, my cabbage may be used by close people in informal communicative situations.

So, me may conclude that the Ukrainian formulas of address are more numerous and diverse, they convey different emotional shades and carry more information about the relations between communicants, which is predetermined by the collectivist type of culture, And the use of addressing terms depends on a variety of contextual factors, relationships between interlocutors, and individual characteristics of interlocutors such as age, gender, education, social status and others.

\section{References:}

1. Березович Е.Л. Язык $u$ традиционная культура: Этнолингвистические исследования. Москва: Индрик, 2007. 600 с.

2. Веремьев А.А. Введение в культурологию: учебное пособие. Брянск: 7. Курсив, 2000. 248 с.

3. Lambrecht, K. (1996). Conceptual Structure, Discourse and Language. Edited by Adele E. Goldberg Publications. Center for the Study of Language and Information Stanford, California, pp. 267-288.

4. Nordquist R. Vocative: Definition and Examples. URL: https://www.thoughtco.com/vocative-grammar-1692598 